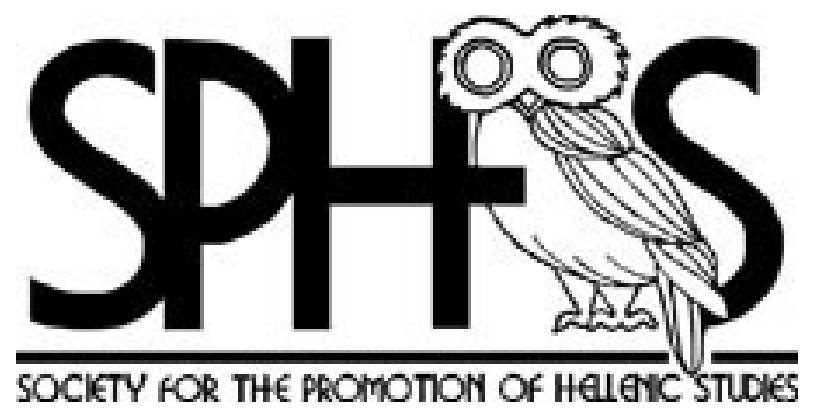

The Battles of Andros and Cos

Author(s): W. W. Tarn

Source: The Journal of Hellenic Studies, Vol. 29 (1909), pp. 264-285

Published by: The Society for the Promotion of Hellenic Studies

Stable URL: http://www.jstor.org/stable/624686

Accessed: 23/12/2014 18:35

Your use of the JSTOR archive indicates your acceptance of the Terms \& Conditions of Use, available at

http://www.jstor.org/page/info/about/policies/terms.jsp

JSTOR is a not-for-profit service that helps scholars, researchers, and students discover, use, and build upon a wide range of content in a trusted digital archive. We use information technology and tools to increase productivity and facilitate new forms of scholarship. For more information about JSTOR, please contact support@ jstor.org.

The Society for the Promotion of Hellenic Studies is collaborating with JSTOR to digitize, preserve and extend access to The Journal of Hellenic Studies. 


\section{THE BATTLES OF ANDROS AND COS.}

No apology should be needed for treating afresh these much-discussed battles, if only because the last two years have produced new and important evidence from Delos ; though in fact the literary allusions, scanty as they are, have hardly even yet been sufficiently elucidated. I hope in this paper to fix the dates of Andros and Cos by the Delian archon-list, and to consider what that means in terms of B.C. In a subsequent paper, to be published in the next number of this Journal, I hope, by working out the history of the ship which Antigonus Gonatas dedicated to Apollo, to confirm the date assigned to Cos in this paper. If these two dates could really be fixed, they would be invaluable for our understanding of Aegean history in the middle of the third century.

The problem of the two battles is not identical; for while of the three current theories of Andros one must be right, both the current theories about the date of Cos may conceivably be wrong. The existing opinions are as follows:- ${ }^{1}$ Andros. (i) A victory won by Antigonus Doson (who reigned 229-221/0 в.c.) about 228 в.c. ; Beloch ${ }^{2}$ and the majority of scholars since. ${ }^{*}$ (ii) A victory won by Antigonus Gonatas (who was king of Macedonia from 276 to 239 B.c.) in the Third Syrian war, 247-243 в.c. ; C. Müller, in F. H. G. ad loc., followed by Kaerst, ${ }^{4}$ Niese, ${ }^{5}$ Bouché-Leclercq. ${ }^{6}$ (iii) A defeat sustained by Gonatas in the Third Syrian war; Droysen, ${ }^{7}$ followed by several Italian writers, G. A. Levi, ${ }^{8}$ G. Corradi, ${ }^{9}$ Gaetano de Sanctis. ${ }^{10}$ Cos. No question arising as to who fought and won this battle, the only matter is the date. Beloch (l.c.), followed by the majority, puts it circ. 258-6;

1 See A. Bouché-Leclercq, Hist. des Lagides, vol. iv. p. 316.

2 Griech. Gesch. iii. 2, §174.

3 J. Delamarre, Rev. Philol. xxvi. (1902), p. 321 ; F. P. Garofalo, Rendic. dell' Accad. dei Lincei (cl. di sc. morali) ser. 5, vol. xi. (1902), p. 147 ; F. Dürrbach, B.C.H. xxviii. (1904), p. 108, n. 3 ; G. Cardinali, Riv. di Storia Antica N. S. ix. (1904-5), p. 93 ; Costanzi, Bollettino di Filol. class. xi. (1904-5), p. 156 ; P. Roussel, B.C.H. xxxi. (1907), p. 360 ; M. Holleaux, B.C.H. xxx. (1906), pp. 60, 61 ; xxxi. (1907), pp. 94, 104 (very emphatic).

4 Antigonus (4) in Pauly-Wissowa.

5 Gesch. d. Gr. «. Mak. Staaten, ii. 150.

${ }^{6}$ Histoire des Lagides, 1, 256 ; iv. 316. It will be seen that Prof. Bouché-Leclercq is the only writer who, writing since Dr. Beloch, supports this theory.

7 Hellenismuss, ${ }^{2}$ iii, 405.

${ }^{8}$ Atti della R. Accad. delle Scienze di Torino, vol. 39 (1904), pp. 629 seq.

9 Ibid. vol. 40 (1905), pp. 805 seq., 814, n. 2

${ }_{10}$ Most recently in Klio ix. (1909), pp. 1 seq. 
C. F. Lehmann-Haupt, ${ }^{11}$ following Droysen, puts it earlier, in the Chremonidean war.

I will take the evidence for Andros in the following order:-Trogus, Plutarch, M. Holleaux's inscription from the North portico at Delos, and the Delian inventory of Stesileos published by M. E. Schulhof; this last raises the chronological question proper for both battles. As my views about both battles will differ from those of Dr. Beloch, I should like to express here once for all my great obligations to the essay on the subject, in vol. iii. 2, of his Griechische Geschichte, an essay without which this paper could not have been written.

\section{A.-Trogus Pompeius.}

Trogus, Prol. 27. Ut Ptolomaeus Adaeum denuo captum interfecerit et Antigonum (C. Müller: Antigonus) Andro proelio navali prona (C. Müller: Sophrona) vicerit. It was because this notice comes in the text between the deaths of Ziaelas and of Antiochus Hierax that Beloch, who dates these deaths in 229 and 227 respectively, assigned the battle to Doson's Carian expedition. But the utmost that could be allowed to this argument is a kind of probability; for Trogus, as has often been pointed out (and by no one more forcibly than by Beloch himself), does not necessarily give events in chronological order. ${ }^{12}$ And this lack of chronological order leaves the question, so far as Trogus is concerned, and in spite of all attempts to treat it as res judicata, absolutely open.

It occurred to me to analyse Trogus' use of ambiguous proper names, Ptolemy, Antiochus, etc., and see if anything came of it. For whether he be entirely Timagenes, or Timagenes and others, or even partly himself, he at any rate put his history together for readers who were probably sufficiently unfamiliar with the Hellenistic dynasties to be puzzled by their habit of all using the same name. I will first give the result of my analysis, and then the analysis itself.

Trogus acts on three fixed rules. (a) Generally, a king on the first mention of him is introduced, either by his surname, or by some unmistakable relationship or office, or both. (b) If in any case both surname and relationship are omitted in the introduction of any king, it is where the death of the predecessor has just been recorded, so that no ambiguity can arise. (c) Once a king is 'on the boards,' he is thereafter referred to merely as Ptolemy, Antiochus, etc., unless (i) there are two of the name at once, when surnames are given, or (ii) there is a digression, or a very long reign, when the surname is sometimes repeated as a refresher.

These rules apply in every case except that of Alexander's own generals,

11 Klio v. (1905), p. 391.

12 The latest list of instances is that of de Sanctis in Klio ix. 1, who remarks that to collect them is to carry vases to Samos. Beloch's words are in $G r$. Gesch. 3, 1, 638 n. 5: 'wenn im Inhaltsverzeichnis zu Trogus' 26 Buch erst der Krieg zwischen Antigonos und Alexandros, dann die Befreiung von Sikyon erwähnt wird, so beveist das bei der Art, wie dieses Werk disponiert war, chronologisch nicht das geringste.' (italics mine.) 
the first Ptolemy, Antigonus, etc., where no mistake is possible. Their object can be summed up in a line: economy of statement with avoidance of ambiguity. It looks as if the prologues had been written consecutively, as a sort of synopsis of contents.

To prove the foregoing:

Lagids.

16, 6. Introduction of Ptolemy II. as Ptolomaeus (i.e. Soter) nuncupato successore filio Philadelpho decessit $(a)$.

17, 6. Introduction of Ptolemy Ceraunus as Ptolomaeo fratre Arsinoes uxoris Lysimachi (a).

17, 7 and 24, 4. Ptolomaeus Ceraunus (c (i) two Ptolemies at once).

26, 10. Ptolomaeus alone $=$ Philadelphus $(c)$, Ceraunus being dead, 24, 7 .

27, 2. Introduction of Ptolemy III. as Ptolomaeum Tryphonem (a).

27, 6. Ptolomaeus alone $=$ Ptol. III. $(c)$.

30, 2. Mortuo Ptolomaeo Tryphone. A refresher (c (ii), 4 books having elapsed).

,$\quad$ Introduction of Ptolemy IV. as filius ejus Philopator $(a)$.

34, 6. Introduction of Ptolemy V. as Ptolomaeus Epiphanes (a).

, Ptolomaeo alone = Epiphanes $(c)$. arises.

After this every 'Ptolomaeus' has his surname given, so no question of ambiguity

Seleucids.

17, 9. Introduction of Antiochus I. as Antiocho alone, following upon Seleucus interfectus $(b)$.

24, 2. Antiochum Seleuci filium (c (ii), a refresher, 6 books having elapsed).

25, 4. Antiocho alone $=$ Soter $(c)$.

26, 8. Antiochus cognomine Soter... decesserit. Surname given as being recently acquired.

26, 8. Introduction of Antiochus II. as altero filio occiso altero rege nuncupato Antiocho decesserit (Antiochus I.) (a).

26, 12. Antiochus alone $=$ Theos $(c)$.

26, 13. Introduction of Seleucus II. as Seleucus Callinicus (a).

27 , 1. Seleucus alone $=$ Callinicus $(c)$.

27, 3. Introduction of Antiochus Hierax by both names (a).

27, 8. Antiochus alone $=$ Hierax $(c)$, Theos having died 26,13 .

27,10 . Seleucus alone $=$ Callinicus $(c)$.

30,2 . Introduction" of Antiochus III. as Antiochum regem simply (b), the deaths of his father Callinicus, of Hierax, and of Seleucus III. having all been given $2 \overline{\mathbf{i}}, 10$ and 11 .

30 and 31. Antiochus alone 4 times $=$ Antiochus III. (c).

32,15 . Introduction of Seleucus IV. and Antiochus IV. as mortuo Seleuco filio magni Antiochi successit regno frater Antiochus ( $a$ in both cases).

34. Antiochus alone thrice $=$ Epiphanes $(c)$.

35, 5. Antiocho Epiphane, because he had died 34, 11.

Antigonids.

15, 2. Introduction of Demetrius I. as Demetrius Antigoni filius (a).

15,5 and 7 , and 16, 3. Demetrius alone thrice (c), and his death.

24, 2. Introduction of Antigonus II. as Antigonum Gonatam (a).

25. Antigonus alone twice $=$ Gonatas.

26, 2. Antigonus Gonatas (c (ii), a refresher).

26, 11. Antigonus alone $=$ Gonatas $(c)$. and his death.

Introduction of Demetrius the Fair as frater Antigoni Demetrius (a), 
27, 7. Antigonus alone $=$ Gonatas (c), the passage in question. his death.

28 , 4. Introduction of Demetrius II. as rex Macedoniae Demetrius (a), and

28, 5. Introduction of Antigonus Doson as tutelam filii ejus Philippi suscepit Antigonus $(a$ and $b)$.

32, 6. Introduction of Demetrius, eldest son of Philip 5, as alter filiorum (Philippi) Demetrius $(\alpha)$.

It appears from the above that a new king, on his first mention, has in every case an introduction, after which his name simply runs on; and that the king's reigns, unlike the contents of those reigns, are kept in chronological order. The introduction of Doson occurs in 28,5, after the death of Demetrius II; and the Antigonus of 27, 7, prior to the introduction of Demetrius II in 28, 4, is simply Gonatas' name running on, as it has run on five times previously with one refresher. It is quite impossible that it can refer to Doson; no king is referred to before his introduction.

Trogus then shows that the battle of Andros was fought by Antigonus Gonatas against the generals of Ptolemy III. Whether it was a victory or a defeat, Trogus does not and can not show; for the sentence as it stands contains two accusatives and no nominative; emending it may make grammar, but cannot make history. De Sanctis' ingenious conjecture 'per Sophrona,' ${ }^{13}$ and Levi's ingenious argument from Trogus' use of et and ut, ${ }^{14}$ end as they began: they are conjectures. And the view that Andros was a Macedonian defeat rests solely on such conjectures.

\section{B.-Plutarch.}

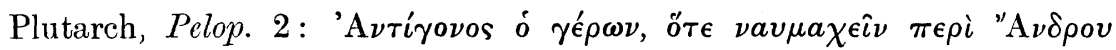

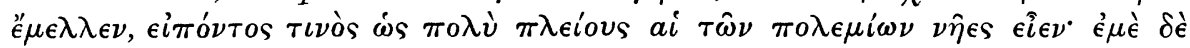

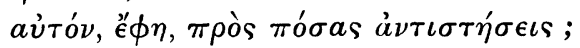

Plutarch then attributes the battle of Andros to Antigonus ó $\gamma \in$ f́ $\omega \nu$, and tells a story about it which he also tells about the victory of Antigonus o $\delta \epsilon u ́ \tau \epsilon \rho o s$ at Cos. ${ }^{15}$ The story in itself imports a victory; and though it is clear that a confusion has been made between Andros and Cos, and that the story can belong originally to one of the two battles only, it is equally clear that, as Cos was a Macedonian victory, ${ }^{16}$ Andros was a victory also, or no confusion could have arisen. Those who treat Andros as a Macedonian defeat simply dismiss Plutarch from consideration. I grant this much, that the confusion requires explanation; I hope to explain it in my second paper.

Who now was Antigonus $\dot{o} \gamma \in \hat{\epsilon} \rho \omega \nu$ ? Beloch suggested a corrupt reading for $\Delta \omega \sigma \omega \nu ;{ }^{17}$ others have suggested a confusion with Monophthalmos. ${ }^{18}$ But

\footnotetext{
13 Atti d. R. Accad. d. Sienze di Torino, 17 Gr. Gesch. iii. 2, p. 431. xxxix. p. 635 ; Klio ix. (1909), p. 1.

14 l.c.

15 Plut. De seips. laudando, p. 545 в ; Apophthegm. regum, p. 183, c.

${ }_{16}$ Ath. v. $209 \mathrm{E}$.

17 Gr. Gesch. iii. 2, p. 431.
18 I need hardly say that the reference to

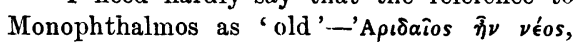

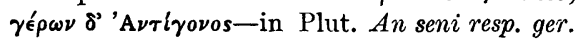
sit, $791 \mathrm{E}$, has nothing to do with the phrase $\delta$ $\gamma \in \hat{\epsilon} \rho \omega \nu$.
} 
the obvious way to find out is to look at the other passages-there are, I think, only two-where Plutarch uses the phrase.

The first one, ${ }^{19}$ though an excellent story, merely shows that the Antigonus in question had some interest in philosophy; this no doubt best suits Gonatas, but is indeterminate.

The second ${ }^{20}$ is fortunately quite clear. A certain Hermodotus, a poet, called the Antigonus in question 'son of the Sun and god;' to which Antigonus made the perhaps then original reply that he was no such hero to his valet. 'The allusion in 'son of the Sun' is to the famous ithyphallus once made in honour of Demetrius I, and sung all over Athens (and small wonder, if the tune were as catching as the words), in which Demetrius among his friends is called the Sun among the stars. ${ }^{21}$ The Antigonus then who was the 'son of the Sun' was Gonatas.

What now does the phrase ó $\gamma$ '́ $\rho \omega \nu$ mean? It is literally, Antigonus the old man; and if I write it, Antigonus 'The Old Man'-or better (if I may be pardoned the slang of it) 'Old Man Antigonus'-we see at once. It was a nickname. Gonatas at the end of his life had outlived every one of his contemporaries. All the great figures of his generation, who had played their parts on the political stage-the two Antiochi of Syria, Pyrrhus of Epirus and Areus of Sparta, Magas of Cyrene and Demetrius the Fair, Philetairos of Pergamum and Alexander of Corinth, chiefest of all Ptolemy Philadelphus of Egypt-all were dead; Antigonus alone remained, the 'old man' of the political world. We have seen a somewhat similar nickname given to a statesman in our own time. ${ }^{22}$

Plutarch then confirms the fact that Andros was fought by Gonatas, and implies that it was a victory for him.

\section{C.-The North Portico at Delos.}

In the portico on the north side of the temenos of Apollo at Delos, formerly known as the 'portique des Cornes,' M. Holleaux has recently discovered ${ }^{23}$ part of a dedication engraved upon the architrave, which runs as

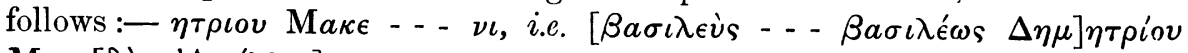

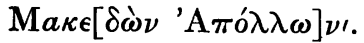

M. Holleaux points out that the king in question is not likely to be Philip V., as he built the South portico; and as between Doson and Gonatas

19 Plut. de Alex. M. fortuna aut virtute, Or. 1. p. $330 \mathrm{E}$.

20 Plut. de Is. ct Osir. p. $360 \mathrm{c}, \mathrm{D}$ : '方文íov $\pi \alpha i ̂ \delta \alpha$ кal $\theta \epsilon \delta \nu . '$ I have never seen this quoted.

${ }^{21} A p$. Ath. vi. 253d.

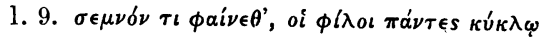

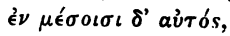

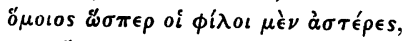
$\eta \lambda \cos \delta^{\prime}$ é $\kappa \epsilon i \nu$ os.

One recalls the mantle made for Demetrius which was left unfinished and which no future king dared wear (Plut. Dem. 41); it was ๕ $\rho \gamma \gamma \nu$

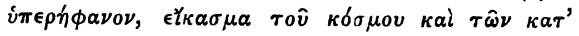

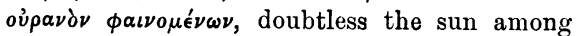
the stars; was the Sun a portrait of Demetrius? We do not of course know if the song referred to the mantle or vice versa.

22 Gladstone.

${ }^{23}$ C. R. Acad. Inscr. 1907, pp. 335 seq. 
he assigns the work to Gonatas, reserving for the present his reasons. A consideration of the inscription shows, I venture to think, that this attribution is quite certain.

Pausanias, when speaking of Ptolemy I. being proclaimed victor at the

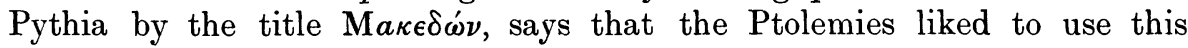

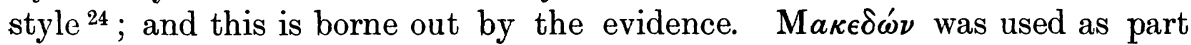
of his style by Ptolemy I., both before he took the title of king, ${ }^{25}$ and after $;{ }^{26}$ by Ptolemy II. $;{ }^{27}$ and by Ptolemy III. and all his family. ${ }^{28}$ It was also used by Antiochus III. of Syria. ${ }^{29}$ On the contrary, we find that Cassander, who was in fact king of Macedonia, does not use it; his style,

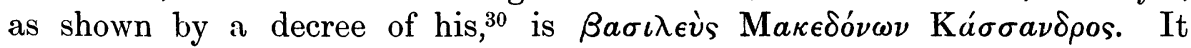

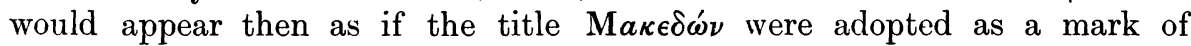
distinction by those kings who reigned over Orientals; and the desire to distinguish himself from the Asiatic must be the reason of its so frequent use by the private Macedonian.

Coming to the Antigonids, we find that Antigonus I. already used the

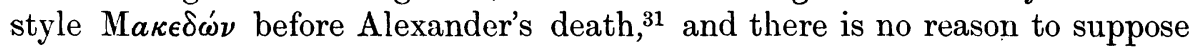
that he would cease to do so when king of a large part of Asia. For Demetrius I. I know of no evidence either way. For Gonatas, however, we fortunately have express evidence in the unpublished Delian inventory of Sosistratos, where he is mentioned as calling himself $\mathbf{M} a \kappa \epsilon \delta \dot{\omega} \nu$ in a dedication. ${ }^{32}$ Gonatas never ruled any part of Asia, so far as we know, and the style is probably a survival of that of his father and grandfather, indicating dormant pretensions that it might be useful to revive should the Seleucids ever revive their claim to the crown of Macedonia.

If now we turn to the other end of the dynasty, we find that Philip V.

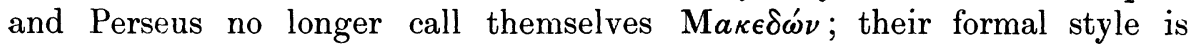

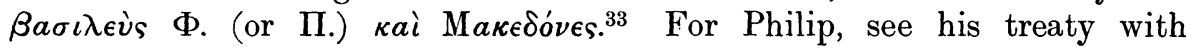
Hannibal $^{34}$ and the proclamation of freedom to the Greeks made by T. Quinctius Flamininus at the Isthmus ${ }^{35}$; for Perseus, the inscription found

\footnotetext{
${ }^{24}$ Paus. x. 7. 8.

25 The Delian inventory of Demares, B.C.H. vi. p. $1=$ Dittenb. Syll. ${ }^{2} 588,1.181, \Pi \tau \sigma \lambda \epsilon-$

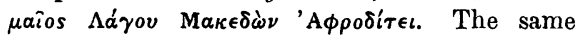
phrase again in 1.112 of a new fragmentary inventory published by F. Dürrbach, B.C.H. xxix. (1905), p. 509, No. 167.

26 Paus. vi. 3. 1.

${ }^{27}$ Implied in 1. 167 of Callimachus' Hymn to

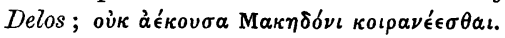

28 'Е $\phi$. 'А $\rho \chi . ~ 1905,91=$ Rev. Ét. Gr. 1907, p. 47 ; a marble exedra from Thermos in Aetolia, supporting the bases of eight bronze statues of Ptolemy III., Berenice, their five children, and an unknown, perhaps a sixth child; the inscriptions remain, and give all

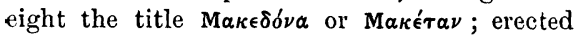
by the Aetolian league.

${ }^{29}$ Dittenb. O.G.I. 239 (from Delos).

30 Dittenb. Syll. ${ }^{2} 178$.
}

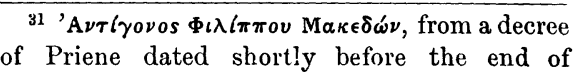
334 в.c. ; Hiller von Gaertringen, Inschriften von Priene (1906), No. 2. I regret that I have been unable to see this hook, and take the title from Rev. Et. Gr. 1907, p. 78.

32 B. 1.21 of this inventory (No. lxxvii. in the list in Homolle, Les Archives de l'In-

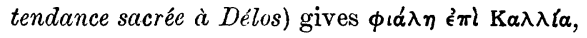

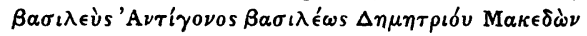
$\Pi \alpha \nu[$ l. (See E. Schulhof in B.C.H. xxxii. (1908), p. 490, n. 2.) It is a vase of Gonatas' foundation Paneia, of which more presently.

33 Instances collected by Holleaux, B.C.H. xxxi. (1907), p. 97.

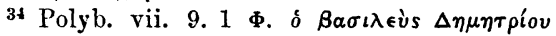

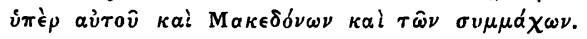
Cf. vii. 9. 5 and 9. 7 .

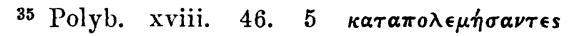

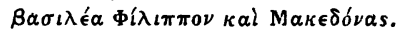


at Delphi, which must belong to the trophy of Aemilius Paulus. ${ }^{36}$ I know

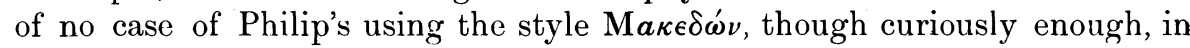
the dedication of his portico at Delos, he returns to Cassander's style and calls himself $\beta a \sigma \iota \lambda \epsilon \dot{v} \varsigma \mathrm{M} a \kappa \epsilon \delta o ́ \nu \omega \nu .{ }^{37}$

Doson's style is the same as Philip's. We possess one very important inscription of his, that set up at Delos after the battle of Sellasia, ${ }^{38}$ which would be bound to show his regular official formula; and, apart from the certain restoration $\mathbf{M} a \kappa \epsilon \delta \delta^{\prime} \epsilon \varsigma$, the letters $\kappa a$ on the stone show clearly that

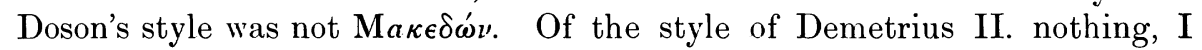
think, is known.

Consequently, beside the main fact that the styles of Gonatas and Doson are different, we see that each of their styles has its regular place in a series which confirms the fact of the difference. Thongh we do not know

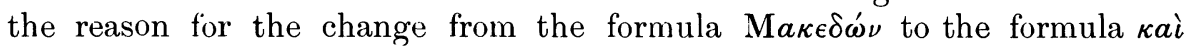

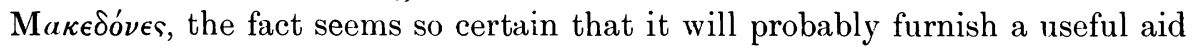
in the notoriously difficult business of distinguishing the inscriptions relating to Gonatas and Doson respectively. ${ }^{39}$

The portico builder, then, who calls himself $\mathbf{M} a \kappa \epsilon \delta \omega \nu$, was Gonatas. He not only built the portico, but dedicated there to Apollo fifteen statues of his ancestors $;^{40}$ this proves that he was at some time of his life lord of Delos in the fullest sense. We might indeed have inferred as much long ago from an inscription found in the Propylaea at Delos, which shows that at some time during Gonatas' life-time some one dedicated at Delos a statue of his wife Phila, ${ }^{41}$ a dedication which certainly could not have been made so long as Delos and the League of the Islanders were under the suzerainty of Egypt, Gonatas' perpetual enemy; no rómos could in such circumstances have been voted for a statue of the Macedonian queen. ${ }^{42}$ Now we know that during all

36 B.C.H. 1897, p. 621. L. Ajmilius L. F. Inperator De Rege Perse | Macedonibusque cepet.

37 B.C.H. ii. (1878), p. 78, No. 31, and

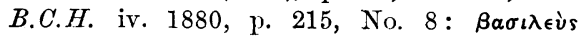

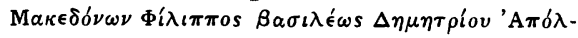
$\lambda \omega \nu$. I have not seen the paper by H. Gaebler in Num. Zeit. xx. in which I am told that he proves conclusively that the smaller silver and

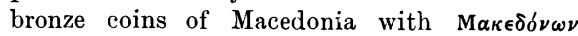
belong to the reign of Philip V.

38 Published by M. Holleaux, B.C.H. xxxi. pp. 94 seq. As completed by Holleaux, it runs as follows :-

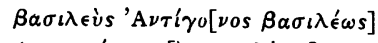

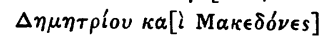

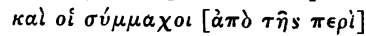

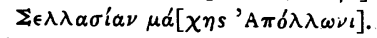

39 For instance, the two inseriptions from Crete which record treaties of Eleuthernae and

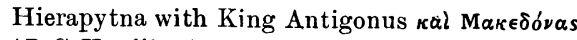
(B.C.H. xiii. 47 ; J. Delamarre in Rev. Philol. xxvi. (1902), pp. 301 seq. Nos. 7 and 8) certainly refer to Doson (so Delamarre, against G. Doublet in B.C.H. l.c.) : while the inscription from the Asclepieion at Epidaurus, I.G. iv. No. 1419,

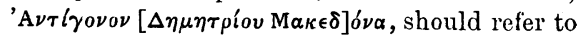
Gonatas, and not to Doson, to whom Fraenkel assigns it.

${ }^{40}$ M. Holleaux in C.R. Acad. Inscr. 1908, pp. 163 seq.

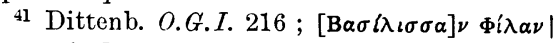

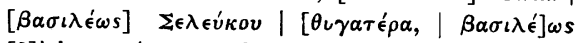

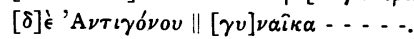

${ }^{42}$ The conclusive arguments of Holleaux in this connection in B.C.H. 1907, pp. 94 seq., referring to the Sellasia inscription, are equally applicable to Phila's statue : I need not repeat them. A good instance of the formalities connected with the grant of a rómos is supplied by the decree of Histiaea, Dittenb. Syll. ${ }^{2}$ No. 245, to which is appended the Delian decree granting the $\tau$ ónos. 
the early and middle part, at least, of Philadelphus' reign the Aegean was an Egyptian lake and the League little better than an Egyptian province; and we do not know that any change took place during Philadelphus' lifetime. When the change which made Gonatas lord of Delos did take place, it can only have been the result of a naval victory or victories gained by that king. We have therefore now got as far as this: that either Cos or Andros, or the combined effect of both, transferred the mastery of Delos from Egypt to Macedonia in such complete fashion that Gonatas saw fit to build a large addition to the temenos and there set up numerous statues of his ancestors, i.e. he considered the transfer permanent. This cannot, as we have seen, have happened earlicr than towards the end of the reign of Philadelphus.

\section{D.-The Soteria and Paneia.}

M. E. Schulhof has recently published a new Delian inventory, ${ }^{43}$ belonging to the end of the third century and the archonship of Stesileos. By combining the information it gives with that which he derives from the published inventory of Sosisthenes and the unpublished mutilated inventories of Acridion (240 B.C.), Boulon (234), Menethales (229), and No. LIX. of the list in Homolle's Archives (224), he has produced a list of fêtes in Delos which marks a great advance on our previous knowledge. Year by year, at each of these fêtes, a vase $(\phi \iota a ́ \lambda \eta)$ was provided from the interest of a sum of money given for that purpose by the founder of the fête, and dedicated. If we know the year in which a given series of vases commences, and know, or can deduce, who the founder was, his act may throw light on the historical circumstances which led him to make his foundation. It goes without saying that, as M. Schulhof's results largely depend on unpublished documents, I can only accept those results as he gives them. The dates in this section of this paper are those of M. Homolle's list of Delian archons.

The foundations to which I shall have to refer are three series of vases offered by a Ptolemy, three series by an Antigonus, one by a Demetrius, and one by a Stratonice; and five fêtes known as the Theuergesia, Soteria, Paneia, Philetaireia and Philadelphia.

Of the Ptolemaic foundations, one dates from seven years before the archonship of Sosimachos in 276, =283, one from the archonship of Badros, 248, and one from the archonship of Mantitheos, 245. The Theuergesia also dates from Mantitheos, but I do not gather that Sclulhof identifies it with the Ptolemaieia of the same year.

Of the Antigonus foundations, one dates from the archonship of Phanos, 252, and the other two from that of Xenocrates, 244. All three therefore belong to Gonatas; and, incidentally, a number of vases that used to be attributed to Doson are shown to be merely vases of these foundations. Schulhof further identifies the Soteria and Paneia with the two latter foundations of Gonatas in 244.

${ }^{43}$ B.C.H. xxxii. (1908), pp. 97 seq. (part 2 of No. 21). 
Stratonice's foundation dates from Phanos, 252. That of Demetrius dates from the archonship of Timagenes, 237 : he is therefore Demetrius II.

So far M. Schulhof. It remains to consider what it all means.

First, the Theuergesia. ${ }^{44}$ It seems impossible that this word can be derived from anything but the words $\theta \epsilon o \hat{v} \epsilon \dot{v} \epsilon \rho \gamma \epsilon \in$ Tov or $\theta \epsilon \hat{\omega} \nu \epsilon \dot{v} \epsilon \rho \gamma \epsilon \tau \hat{\omega} \nu$, whether the festival was founded by Ptolemy III. or by another in his honour. This is of the first importance. Probably it will ultimately be identified with the Ptolemaieia of the same year; but this is not material here. Whether one festival or two, the point is that in Mantitheos' year Ptolemy III. signalises his recent accession by a perpetual foundation at Delos. The statement therefore of the Adulis inscription, that he inherited the overlordship of the Cyclades, ${ }^{45}$ is absolutely correct; and in Mantitheos' year Gonatas is not lord of Delos.

The first Ptolemaieia, of 283 , is unmistakable: it celebrates the transference of the league of the Islanders to Ptolemy on the fall of Demetrius I. The remaining Ptolemaieia of 248, which must have some relation to the Antigoneia of 252 , will be more conveniently considered with the latter festival.

I come now to the Antigonus foundations of 244; and first the Soteria.

Such a word ought to refer to a victory or some historic event. In considering it, two inscriptions are material: the famous decree from Nicourgia of the synedroi of the league of the Islanders, ${ }^{46}$ and the decree of the $\beta o v \lambda \eta^{\prime}$ and $\delta \hat{\eta} \mu o s$ of Delos in honour of Philocles. ${ }^{47}$ The first decree shows, among other things, that Ptolemy I. had freed the island states ; ${ }^{48}$ that the Islanders, first of all men, had honoured Ptolemy 'the saviour' with honours equal to those paid to the gods ; ${ }^{49}$ and that there was at Delos an

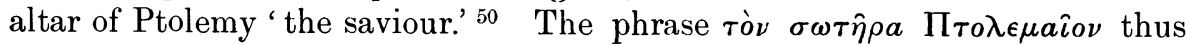
twice repeated in connection with the honours paid to Ptoleniy I. by the League is remarkable; for when it refers to Ptolemy I. in connection

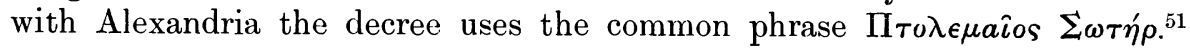
I think, with Dittenberger, that the language of the decree will not support Delamarre's conjecture, that it was the Islanders, and not the Rhodians, who first gave Ptolemy I. the name $\Sigma \omega \tau \eta \rho{ }^{52}$ but I also think that the decree plainly shows that the 'godlike honours' rendered to Ptolemy I. were rendered to him specifically by the name of, and as, $\dot{o} \sigma \omega \tau \eta \dot{p} \rho$,

44 We used to know it as Euergesia; but the new rending is said to be absolutely certain; Schulhof, l.c. p. 116, n. 3. Schulhof remarks that it is certainly formed from the singular,

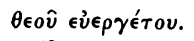

45 Dittenb. O.G.I. 54.

46 Dittenb. Syll." 202 ; J. Delamarre, Rev. Philol. xx. 104 ; I.G. xii. 7, 506. It belongs to the early years of Philadelphus.

47 Dittenb. Syll. ${ }^{2} 209$. Near in time to the Nicourgia decree, and therefore after the fall of Demetrius.

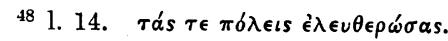

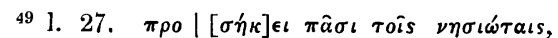

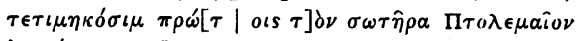

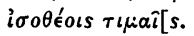

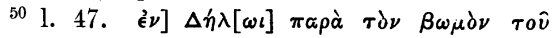
$\sigma \omega \tau \hat{\eta} \rho o s[\Pi \tau] o \lambda \epsilon[\mu \alpha i ́] o v$.

51 1. 57. For the usual form, see e.g. the dedication by the Islanders, Dittenb. O.G.I. 25, and a decree of the League (Dittenb. O.G.I. 67) as completed by P. Roussel in B.C.H. xxxi. (1907), p. 340 , No. 3, 1. 25.

52 In Rev. Philol. xx. 104. Followed by Hiller von Gaertringen, Thera, 1, 163. 
the saviour (i.e. of the Islanders), and were connected with his 'freeing' the Islanders from the rule of Demetrius I.53 The festival then in honour of Ptolemy I., at which he received godlike honours, was probably a 'soteria' festival; and this is rendered all but certain by the second decree, in which the people of Delos vote to sacrifice soteria for Philocles in Delos, and also to Zeus Soter in Athens. ${ }^{54}$ For Philocles king of the Sidonians exercised, during the early part of the reign of Philadelphus, almost vice-regal authority in the Aegean, authority superior to that of the nesiarch and not again (so far as we know) conceded to any Ptolemaic officer; and,judging by his peculiar position, the $\sigma \omega \tau$ ŕp $\rho a$ sacrificed for him can only have one meaning; he had been Ptolemy's instrument to 'deliver' the Islanders from Demetrius. The Soteria festival of Antigonus was then a proclamation to the world that the tables were now turned, and that the 'deliverance' of the Islanders by Ptolemy I. and Philocles from Demetrius I. had been repaid by a 'deliverance' from Ptolemaic rule wrought by Demetrius' son; and it is therefore most probable that the festival would actually celebrate the 'crowning mercy' that transferred the Cyclades from Egypt to Gonatas. It therefore probably commemorates one, or both, of the naval battles, Cos and Andros.

Now we have three festivals founded at Delos by Gonatas, and three important events, connected with his navy, in the latter part of his reign: Cos, Andros, and the recovery of Corinth. Do the three festivals belong to the three events? Beloch has assigned the foundation of 252 to Cos; and as every one places Andros after Cos, it looks very simple to assign the Soteria to Andros and the Paneia to the recovery of Corinth. I am afraid, however, it is not really as simple as this. There is no reason for putting Andros later than Cos; it has been done merely because Droysen did so. And Dr. Beloch's date for Cos depends on the fact that he found one Antigonus foundation at Delos, dating from 252, which seemed to import a naval battle: had the Paneia and Soteria been known when he wrote, I venture to think that he might have come to a different conclusion.

I turn then to the Paneia with the premiss that the whole question is res integra.

There are two coins of Gonatas with Pan as a type: one shows Pan's head on a Macedonian shield, the other, Pan before a trophy, with a much discussed symbol in the field. Usener, in an important article, ${ }^{55}$ after shewing that these pieces should refer to a 'panic' victory, assigned them to Gonatas' victory over the Gauls at Lysimachea; with the same event he connected Aratus' 'Hymn to Pan,' and concluded that Pan became, so to speak, Gonatas' patron deity. One need have no doubt of the correctness of this as regards the common (and therefore early) pieces with Pan's head on a shield, which shield seems to import a land battle; but the case of the coins with Pan before a trophy is different. These coins have been discussed by

\footnotetext{
${ }^{53}$ On this last point, F. Diirrbach in B.C.H. xxxi. pp. $208 \mathrm{seq}$.

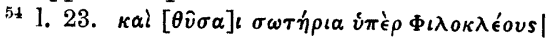

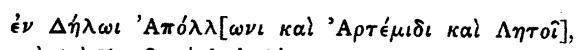

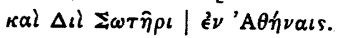

${ }^{55}$ Rh. Mus. 29 (1874), p. 36.
} 
Dr. Imhoof-Blumer; ${ }^{56}$ and as the symbol on them, which is found widely spread on a large number of other coins, replaces, on Syrian and Phoenician coins, in the hands of Astarte and Tyche, a helm, aphlaston, or trident, all marine objects, he draws what seems to be the very just conclusion that the symbol itself must be a marine object. As then the trophy shows that the coin celebrates a battle, and the marine symbol imports a naval battle, these coins ought to refer to Cos or Andros. ${ }^{57}$ But we already know of a coin which celebrates the battle of Cos, Gonatas' tetradrachm with Apollo seated on the prow of a ship; ${ }^{58}$ and the attribution seems quite certain, owing to the story of the ship dedicated to Apollo, which belongs to Cos. The coins, then, with Pan and the trophy more probably belong to Andros; and the Paneia must follow the coins. If so, the Soteria will belong to Cos; and we get the following result: both battles belong apparently to the same year, and Cos was the later and decisive one. ${ }^{59}$ It is obvious from geographical considerations that if both battles belong to one and the same victorious Macedonian campaign Cos must be the later one ; and in my second paper I shall hope to give a quite independent reason for believing that Cos was the later and the decisive battle.

It seems then that both battles fall in the archon year of Xenocrates at Delos, i.e. in the Delian year next after the Delian year (Mantitheos) which, as we see from the Theuergesia, witnessed the accession of Ptolemy III. Can we translate this year into terms of B.c.? It will be well, before returning to the Antigoneia of 252 , to consider this question.

\section{E.-The Chronology proper.}

The point, put briefly, is that the dates of the Delian archons as given by M. Homolle ${ }^{60}$ will probably have to be altered, because M. Schulhof ${ }^{61}$ has discovered more new archons than there are gaps in Homolle's list; consequently we cannot merely now say that a battle fought in Xenocrates' year was fought in 244. Now Homolle's list depends largely on documents still unpublished; and naturally in these circumstances I cannot presume to do more than argue from the material he gives. There are, however, certain

\footnotetext{
56 Monnaies Grecques, pp. 128-130.

${ }_{57}$ Apart from the marine symbol, the trophy would seem to preclude a reference to the recovery of Corinth; for as far as we know there was no fighting. Antigonus merely rapped on the gate of his daughter-in-law's castle.

${ }^{58}$ Figured Head H.N. p. 203. It will be considered in the second paper.

${ }^{59}$ So far as the coins and fêtes alone go, it is conceivable that both coins and both fètes (Soteria and Paneia) refer to Cos. But even were this so, we know that Andros was fought against the generals of Ptolemy III., and on this ground alone there is no other possible
}

place for it, if Cos falls in Xenocrates' year, than just before Cos; for I hope my second paper will show clearly that it cannot fall after Cos. The reference in Diog. Laertius 4, 39 to 'Antigonus' sea-fight' cannot of course be pressed, as against all the other evidence, to show that he fought but one at this time; but two falling in one campaign might well become one in the perspective of a late writer on quite another subject.

${ }^{60}$ Archives. In this section I distinguish Homolle's dates by the letter $\mathrm{H}$.

${ }^{61}$ l.c. 
things in the position which are clear, and may be pointed out; and there are others which, though not clear, may be worth a mention, if only as a means of stating the problems to be faced by whoever shall deal afresh with the chronology of this list.

Homolle's list falls into three sections. The first, running from Lysixenos (301 H.) to Anectos (225 H.), seems to be quite settled as regards the relative order of the archons, so that if we alter one date we must alter all. The same applies to the third section, from Cosmiades (198 H.) to Alkimachos (169 H.). The second section, however, from 224 to 199 (H.), is much more tentative; it contains various queries and two blank years, while the actual succession, which only the greatest skill has pieced together at all, is not necessarily free from doubt.

Schulhof has found 4 new archons (Stesileos, Epikydes, Philon, Timoxenus), who seem to me to be certain, and a fifth, Mantitheos II, who is very probable: ${ }^{62}$ they fall somewhere between 226 and $208(\mathrm{H}.) . \mathrm{He}$ also thinks that ultimately he may have a sixth archon, Lysimachides, to come a little before $240 .{ }^{63}$ Considering then that he has either five or six new archons, and only two vacant places, he proposes to put back the whole of the first section of Homolle's list, from and including Anectos, either three or four years ; this would bring Mantitheos and the Theuergesia to either 248 or 249 , i.e. prior to the accession of Ptolemy III. as generally received. He reserves detailed reasons for future treatment.

Now it seems obvious that the list cannot be dealt with off-hand in this fashion, and I do not suppose that Schulhof intends to do so when he comes to details. For if Ptolemy III. came to the throne in $247 / 6$, the date accepted on the authority of the Ptolemaic 'Canon of Reigns' 64 (of which more presently), we cannot possibly put the Theuergesia and Mantitheos earlier than 247 (i.e. two years back), without first showing either that the Theuergesia have nothing to do with Ptolemy III. or that the 'Canon of Reigns' is wrong. And if Demetrius II. ascended the throne in 239, a date fixed by the joint operation of Polybius and the Roman consul-list, ${ }^{65}$ then we cannot put the Demetrieia and Timagenes earlier than 239 (i.e. two years back), without first showing that Polybius is wrong.

Polybius may be wrong: he is not speaking of a contemporary event. But remembering who Polybius was, and the relations in which the Achaean League stood to the Macedonian kings, it is not likely that he would be mistaken about the length of the reign or the date of the death of Demetrius II. Anyhow it will take a lot of proving.

Equally, the 'Canon of Reigns' may be wrong. ${ }^{66}$ But the Ptolemaic chronology built up on it has so far stood well, and I fancy that the

\footnotetext{
${ }_{62}$ But not certain. The name comes in the inventory of Stesileos, most of which is in no kind of order, chronologically ; cousequently he might be identical with the Mantitheos of 245 (H.).

${ }_{63}$ l.c. p. 479 , n. 1.

${ }^{64} \kappa \alpha \nu \dot{\omega} \nu \beta \alpha \sigma \iota \lambda \epsilon \iota \hat{\omega} \nu$, commonly called the

'Canon of the Kings.' On the trauslation, see Bouché-íeclercq, Hist. des Lagides, ii, Appendix.

${ }^{65}$ See Beloch, Gr. Gesch. iii. 2, p. 72.

${ }^{66}$ I mean wrong by a year or more. It is well known that it takes no count of fractions of a year ; e.g. where two reigns divide a year, the whole year is reckoned to the later reign.
} 
'Canon' will take a good deal of demolishing. Certainly it cannot be done without full consideration.

Lastly, one does not see how it is to be contended that the word Theuergesia is not formed from, and does not represent, $\theta \epsilon o \hat{v} \epsilon \dot{v} \epsilon \rho \gamma \in \dot{\tau} o_{0}$; and Ptolemy III. cannot well have been $\theta \epsilon o$ s before his accession. ${ }^{67}$ The earliest

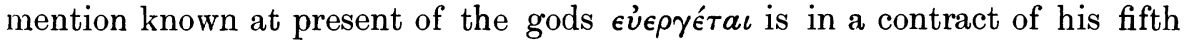
year; ${ }^{68}$ while it appears from a contract dated in his third year that the gods Euergetae had not at that time been associated in the cult of Alexander. ${ }^{69}$ This, however, does not prove that the divine pair may not have already been canonised in another connection; and indeed it is likely enough that the title Euergetes was bestowed on the king directly after his accession. ${ }^{70}$

How then are we to deal with the new Delian archons, assuming that we have five at any rate, and may perhaps have a sixth, with only two gaps in Homolle's list? We shall find that the five can, with the gaps, probably be accommodated by moving the first section of the list two places back and the third section one place forward. It will probably be sufficient to consider the sixth archon if and when he 'materialises,' and meanwhile merely to suggest certain lines of less resistance than the running of a tilt against the 'Canon of Reigns.'

I will take the third section first. The archon-list proper ends with Alkimachos (169 H.); but for the three years 168-166 (H.), though we have no archon-names, we have three colleges of hieropes, two hieropes for each year; then comes the Athenian archon Poseidonios. Here, on the face of it, there appears to be a further gap. For the Athenian year began with the first of Hecatombaion, corresponding to some point in July-August; and Poseidonios' year of office is the Attic year 165/164. ${ }^{71}$ But Athens is supposed to have recovered Delos some time in the year $166 / 5 ;{ }^{72}$ and as the Athenian archons prior to Poseidonios are said not to appear, ${ }^{72}$ the last Delian executive ought to fall, not in 166, but in 165. For the Delian year began on the first of the Delian month Lenaion, which was pretty nearly our January, so that the Delian year corresponded more or less to our own ${ }^{73}$; consequently the period January to July $165^{74}$ would be left without an executive, unless the last Delian executive occupied that period. The result is that, if permissible on other grounds, Homolle's list of archons for 198-166 both inclusive could be made the list for 197-165 both inclusive.

${ }^{67}$ Even if the Thenergesia were founded in the king's honour by some one else, and Theuergesia were not the original name (just as Hermias' foundation was called Philadelpheia), the Pto'emaieia of the same year show that it must have been the year of the accession.

68 Hibeh Papyri i. p. 331, No. 171, see p. 369 .

69 Ibid. p. 328 , No. 145.

70 Supposing that Bouché-Leclereq (1.c. iii. 77) be right in connecting the origin of the title with the bringing back of Cyrene under the crown of Egypt : the best suggestion yet made.

71 Homolle, B.C.H. x. (1886), p. 9 ; B.C.H. xvii. (1893), p. 164

${ }^{72}$ Homolle, Archives, pp. 26, 27.

73 Homolle, B.C.H. v. (1881), p. 25.

74 That is, the period between the laying down of office by the Delian archon of 166 and the assumption of office by Poseidonius, one Hekatombaion 165. 
This, I think, is not only permitted but demanded by the other existing indications of date. The principal one is part of the inventory of Demares which Homolle transcribes on p. 74 of Les Archives, part of which transcription I repeat in a note ${ }^{75}$ for the sake of clearness. It seems probable that the archonship of Xenon is meant to run on till a new archon is mentioned, and that the gift of C. Livius belongs to Xenon (192 H.) and not to Menecrates (191 H.). Now C. Livius Salinator was the praetor in command of the Roman fleet in the Aegean in 191, and therefore his gift cannot be earlier than 191, though it might be later. Consequently, Xenon cannot well fall in 192 (Homolle), but should be 191, or even later, i.e. the whole of this section (the third) of the list must advance one year, at least, a contingency which Homolle in fact contemplated; ${ }^{76}$ and the other Roman gifts in this inventory will fit in quite satisfactorily, because a commander's gift may well be sent a year or two later than his, command, though it can hardly be sent earlier.

Another indication of date is the connection between Amphicles' year and the crown offered to the praetor L. Hortensius, who commanded the Roman fleet in the Aegean in 170. Hence Homolle put Amphicles in 170.77 But what happened in Amphicles' year was that Delos repaid a loan, which she had borrowed in 170 in order to provide the crown for Hortensius: this repayment therefore, and consequently the archonship of Amphicles, is much more likely to fall in 169 , or even later, than in 170 . If Xenon falls in 191, Amphicles automatically falls in 169 , which suits very well.

We thus get rid of another of the five new archons by shifting the third section of Homolle's list from 198-166 to 197-165, leaving three gaps instead of two in the period between Anectos and Cosmiades, section two of the list.

In view of the possibility of having to account for a sixth new archon, it may be noted that there is a possibility of shifting this third section of the list yet another year forward: for the three years 168-166 (H.) depend only on the names of the hieropes, two for each year. Now in the decade following and including the archonship of Demares $(180 \mathrm{H}$.) we find four times that four hieropes are given for a single year: in all the rest of the list (so far as we have the names of the hieropes), we only once find four hieropes,

\footnotetext{
75 ' 16 phiales, don des trésoriers Phéré- et Pachès, (archonte) Ménécratès. cleidès et Polyxénos, (archonte) Xénon.

4 phiales, don des trésoriers Phérécleidès et Polyxénos, (archonte) Xénon.

2 phiales, don des hiéropes Phokaieus et Ményllos, (archonte) Xénon.

Agrafe d'or, don de Lucius, Romain.

Couronne d'or, don de Titus, Romain, poids : $110 \mathrm{dr}$.

Couronne d'or, don d'Aulus, Romain, poids : $100 \mathrm{dr}$.

Couronne d'or, don de C. Livius, Rom., poids : $100 \mathrm{dr}$.

16 phiales, don deq trésoriers Démostratos

1 phiale, don des Thyestadai, (archonte) Xénon.

20 phiales, don des trésoriers Philonicus et Diactoridès, (archonte) Aristarchos.

1 phiale, don des Thyestadai et des Okyneidai, (archonte) Ménécratès.'

Here follow other objects of Menecrates' year. Phokaieus and Menyllos are the hieropes. of Xenon's year. I have filled in words where M. Homolle with his wide page gives ditto marks.

76 Archives, p. 76.

77 Ibid. pp. 94, 95.
} 
(Charmos, $280 \mathrm{H}$.). It is not known why four hieropes sometimes occur $;^{78}$ and it is possible that the three colieges of hieropes allotted to 168-166 (H.) do not in fact occupy three years.

Other possibilities are, that two archons might fall in one year, one dying during his year of office; and duplication of names. For instance, quite a fair case can be made for Apollodorus I. of 217 (H.) being the same as Apollodorus II. of 196 (H.); but the argument is a long one and need not, I think, be given here. The point is, that if a place should have to be found for Schulhof's sixth archon, there are probably easier ways to follow than that of attempting to overthrow the authority of Polybius and the 'Canon of Reigns.'

It remains to consider the question of finding room for the two remaining archons by taking back two years the first section of Homolle's list, up to Anectos $(225 \mathrm{H}$.) inclusive; thus bringing Mantitheos and Xenocrates from 245 and 244 to 247 and 246 respectively. A perusal of Ch. III. $\S 3$ of Les Archives seems to show that M. Homolle himself evidently felt a good deal of doubt as to whether 227 was not a better date for Anectos than 225; but he seems to have decided for the later date on the ground of the Philadelpheia, which he appears to identify with the first Ptolemaicia, and to have felt bound in consequence to assign the beginning of this festival to 283, the beginning of the undivided reign of Philadelphus, rather than to 285. It has now, however, been shown, not only that the Philadelpheia is identical with the foundation of Hermias and not with the first Ptolemaieia, ${ }^{79}$ but also that Philadelphus reckoned his reign from 285 and not from $283 .^{80}$ Homolle's objection, then, in this respect no longer holds good ; while the possibilities of error in his calculation of the date of Anectos on independent grounds ${ }^{81}$ have also been demonstrated. ${ }^{82}$ Already, in fact, before Schulhof wrote, it had been stated, by one well qualified to speak, that Homolle's dates might require a revision of one or perhaps two years. ${ }^{83}$

If then we move the whole section two years back, how does it stand with regard to our present historical knowledge? The foundation of the first Ptolemaieia will fall in 285, the year from which Philadelphus reckoned his reign: showing, as was natural, that Egypt took over the Cyclades and the League at an earlier period than the death of Demetrius I. in 283, and that the junction of Philadelphus with his father as co-regent refers to this event. The foundation of the Philadelpheia (Meilichides II., $267 \mathrm{H}$.), i.e. the fête of Hermias in honour of Arsinoe Philadelphus, will fall in 269, the year after Arsinoe's death, which is far preferable to three years after. The Philetaireia ('Tynnades, $262 \mathrm{H}$.) will fall in 264, in Philetairos'

78 See Homolle in B.C.H. vi. p. 58, and B.C.H. xiv. p. 417 ; von Schoeffer, Delos, in Pauly-Wissowa, IV. ii. col. 24.86.

79 Schulhof, l.c. p. 114 : a view already suggested by Homolle, Arclives, p. 60, n. 5 .

80 Bouché-Leclercq, Rev. Philol, xxxii. (1908), pp. 129 seq., on Rubensohn's papyri from
Elephantine.

${ }^{81}$ Archives, p. 77, from the number of years' interest owing on a loan.

82 Schulhof, l.c. ; it does not follow that all the intermediate years are owing.

${ }^{83}$ F. Dürrbach in B.C.H. xxix. (1905), p. 441 , on the date of the archon Sosisthenes. 
lifetime, instead of (probably) after his death. ${ }^{84}$ The foundation of the Demetrieia (Timagenes, 237 H.), obviously the accession festival of Demetrius II., will fall in the year of his accession, 239, instead of the meaningless year 237, when moreover he was fully occupied on land.

These reasons, and in particular the accession festivals of Philadelphus and Demetrius II., seem to render it not only desirable but necessary to carry all the dates back two years. There remains, however, one question of notorious difficulty to be considered. To carry the dates back two years pins us down to placing the accession ${ }^{85}$ of Ptolemy III. (Theuergesia and third Ptolemaieia, Mantitheos 245 H.) in the Delian year that corresponds to 247 B.c. Is this correct?

The 'Canon of Reigns,' which employs the 'vague' year and dates each king's reign from the first day of Thoth preceding his accession, makes the accession of Ptolemy III. fall between 1 Thoth 247 and 1 Thoth 246. 1 Thoth was at this time October 24th.

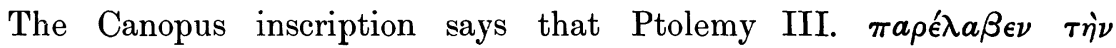

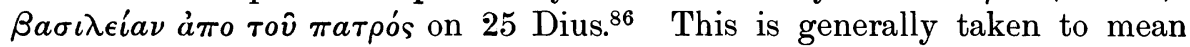
his accession; but Drs. Grenfell and Hunt, while saying that they are disinclined to depart from the ordinary interpretation of the passage, point out that this is not certain, and that it might mean his coronation. ${ }^{87}$ There is no trace of an association of Euergetes I. in the government with his father immediately before the death of the latter.

As to when 25 Dius fell at this time, experts are by no means agreed. Dr. Beloch ${ }^{88}$ makes Dius fall at this time somewhere in the period Phaophi to Choiak inclusive, i.e. roughly December to February. ${ }^{89}$ Drs. Grenfell and Hunt make 25 Dias fall in Athur, Choiak, or Tubi (January, February, March), or anyhow from Phaophi to Mecheir (April) inclusive. ${ }^{90}$ J. Lesquier, very tentatively, places it between 18 Choiak and 25 Mecheir.91 BouchéLeclercq says it is impossible to fix it at all.92

But the question of the relation between the Egyptian vague year of 365 days and the Macedonian year with its intercalated month is only half of the problem. There are papyri of the reign of Euergetes I. bearing double dates and dated apparently on two other systems, one the date of the

8. A difficulty met by Homolle, Archives, p. 61 , by supposing that the foundation might have been made by Philetairos' nephew and successor Eumenes. But the phrase in the inventory of Sosisthenes, quoted by Schulhof,

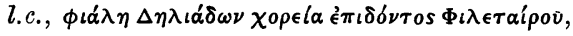
hardly seems consistent with a foundation $\dot{v} \pi \grave{\epsilon} \rho$ $\Phi \iota \lambda \epsilon \tau$ aipov. For the date of Philetairos' death, Beloch, Gr. Gesch. iii. 2, p. 158 ; it is probable that Eumenes came to the throne in 263, as Homolle takes it (Archives, p. 58), but not certain ; and it is possible that Philetairos was still alive in 262 and could have founded the Philetaireia in that year.

${ }^{85}$ The questions involved are discussed by H.S.-VOL. XXIX.
Beloch, Gr. Gesch. iii. 2, $\$ 48$ and refs. ; Grenfell and Hunt, Hibeh Papyri, i. (1906), App. II. ; Bouché-Leclercq, Hist. des Lagides, vol. ii. (1904), App., and vol. iv. (1907), App. I.

${ }^{86}$ Dittenb. O.G.I. 56, 1. 7.

s7 Hib. Pap. i. App. II. p. 363.

88 l.c. $\S 49$.

89 From the table given by Bouché-Leclercq, Hist. d. Lagides iv., App. I., it follows that at this time 1 Phaophi was 23 Nov.

${ }^{90}$ l.c. p. 364.

91 Archiv für Papyrusforschung iv. (1908), 284, 295.

92 Hist. des Lagides iv. p. 295. 
king's 'year,' the other the date of a fiscal or revenue year. ${ }^{93}$ The revenue year is always one higher than the regnal year, i.e. a date in Euergetes I.'s second regnal year would be given as in his third revenue year. Even if the regnal year be identified with the Macedonian year, and the revenue year with the vague year, ${ }^{94}$ these papyri only serve to make an already difficult question even more difficult.

For the present purpose, however, it appears that the experts are inclined to favour the placing of 25 Dius in the beginning of one of our years, without excluding the possibility of its falling at the end of one of our years ; while doubts exist as to whether it can be placed at all, and whether, if placed, it does refer to Euergetes' actual accession. If the date falls in the early part of a year, it would, on the 'Canon,' fall in 246 ; if at the end of a year, in 247: and the difference between December and January is the difference between one archon-year at Delos and the next.

From this, one point, and one only, emerges clearly. The Egyptian evidence, when it comes down to questions of a month or two, is at present of too uncertain interpretation to control the interpretation of any other kind of evidence, i.e. the Delian, which seems fairly clear. We have seen that the Delian evidence, taken in relation to the accessions of Philadelphus and Demetrius II., is pretty clear on one point : it requires Euergetes' accession to fall in 247; and it seems to me that, in the present position of the question, and until the contrary appears, the fair view is that the Delian evidence must control the Egyptian, and Mantitheos and the Theuergesia fall in 247. It will follow, either that 25 Dius was not the actual accession, or that it fell prior to the commencement of a new Delian year in January 246, say in December-Phaophi 247 - both of which views are, as we have seen, possible; or else that the 'Canon of Reigns' is a whole year wrong and that Euergetes I. came to the throne in the early months of 247. The latter possibility, however, with its far-reaching chronological consequences is not one that I can here consider; and I take the view, as being the likeliest at present on the material we have, that the Delian evidence requires the Theuergesia, and consequently Euergetes I.'s accession, to fall in the last days of our year 247, being the Delian year of Mantitheos.

If so, Xenocrates and the battles of Cos and Andros fall in 246.95 This crowds 246 with great events: the taking of Antioch, two or perhaps three

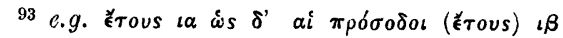
(Hib. Pap. i. p. 338).

${ }^{94}$ See Grenfell and Hunt l.c., and rather more positively Bouché-Leclereq, l.c. iv. p. 295. This would lead logically to Prof. Smyly's view (Hermathena x. p. 432) that from 1 Thoth next following a king's accession to the anniversary of the accession we get regnal year 1 , fiscal year 2; only then we should have to show that all double-dated papyri in a given reign fall in that portion of the year, which it seems cannot be done. s5 I desire, however, to note that, while this seems likeliest at present, the future may shift them a year either way; to 247 , on the ground that the 'Canon' is a year wrong, or to 245 on the ground that other arrangements can be made for one of Schulhof's archons and that the first section of Homolle's list need only go back one place, Euergetes consequently coming to the throne early in 246. But neither result could affect the conclusions of this paper more than to this extent, that two seasons might be allotted to the campaign to which I allot one. 
naval battles, ${ }^{96}$ Euergetes' land campaign. However, this is no more than occurred in 480, a year which saw Xerxes' land march, the battles of Thermopylae, Artemisium, and Salamis, and the taking of Athens; and we feel no difficulty about 480 .

\section{F.--General Sketch.}

It remains to explain the first Antigoneia and the Stratoniceia, connected by Beloch with the battle of Cos, and also the second Ptolemaieia. The most convenient way of doing this will now be to sketch briefly what I consider the course of events. In this section I use the dating arrived at in E, i.e. all dates prior to Anectos two years earlier than Homolle's.

The keynote of Gonatas' ideas and actions, from 276 onward, seems to have been an attempt, while abandoning the impossible parts of his father's policy, to restore his father's kingdom as it was when he was king of Macedonia. 'This included the restoration of his father's sea-power, at any rate in the Aegean, and above all the acquisition of Delos as the centre of the League of the Islanders and the sign and symbol of Aegean sea-power. ${ }^{97}$ His grandfather had probably founded, ${ }^{98}$ his father had certainly controlled ${ }^{99}$ the League ; and on his father's fall Delos and the League and the command of the sea had passed without a struggle to Egypt. He must then have always understood clearly that his ultimate reckoning must be with Egypt. During the earlier part of his reign his hands were too full on land to think of anything else ; Egypt found her profit in his enemies, and remained undisturbed. The Chremonidean war brought the two powers face to face; but Antigonus had no effective fleet, ${ }^{100}$ and the Egyptian admiral seems to have confined his support of his allies to taunting Antigonus with his want of ships, a want easily supplied. ${ }^{101}$ After the war, Antigonus, free at last on land, was able to attend to Egypt. He built a new fleet. About 255 came the great victory of his son Demetrius over Alexander of Epirus, and about the same time

96 If Agathustratos' victory (see post) falls at this time.

97 I cannot attempt to summarise here the voluminous evidence for this latter statement about Delos. See in particular the review by Homolle, B.C.H. vi. pp. $152-162$; and B.C.H. xv. 168 .

98 I have been convinced by Dürrbach, B.C.H. xxxi. (1907), p. 208, that the League was founded between 315 and 308 either by, or under the auspices of, Antigonus I. In the face of his arguments I do not see how the view formerly accepted, that Ptolemy I. fuunded the League in 308 , can possibly be maintained.

99 This follows, not only from his general control of the sea, but from the specific fact that the use of his money in the Cyclades implies his political domination, on which see
J. Delamarre, Rev. Philol. xxviii. (1904), p. 81, No. 1. The Delian inventory of Lysixenos refers to him simply as $\delta \beta \alpha \sigma \iota \lambda \epsilon v^{\prime}$, Homolle, Arch. p. 67, n. 1.

${ }^{100} \mathrm{He}$ had never recovered from his great defeat at sea, about 280, by Ptolemy Keraunos; Mennon in F.H.G. 3, 534, xiii., xiv. In 272 the Achaeans could even capture the ship that brought Nicaea from Naupactus to Corinth, Liv. xxxv. 26. See next note.

${ }^{101}$ Phylarchus ap. Ath. viii. 334a, Patroclus sends Antigonus fish and figs, which Antigonus interprets to mean 'No fish for dinner till we rule the sea.' It reminds one of the Carthaginian admiral declaring that without his leave no Roman should even wash his hands in the sea. The story implies that at the beginning of the war Antigonus' fleet was negligible. 
some form of understanding with Antiochus II., then engaged in war with Egypt(thesecond Syrian war), which led to Demetrius' marriage with Antiochus' sister, the younger Stratonice. In 254 (Phanos' year), Antigonus felt strong enough to sail to Delos with his new fleet; there he founded the first Antigoneia.

The case is peculiar. For at the same time his sister, the elder Stratonice (or more probably Antigonus on her behalf), founded at Delos the Stratoniceia. ${ }^{102}$ It is true that Antigonus had an understanding with Syria; but the elder Stratonice was at this time merely queen-mother, and cannot have officially represented Antiochus or Syrian policy; her foundation must have been made for some reason personal to herself. Stratonice had in her time made many offerings at Delos, distinguished by the fact that, when she mentions relationships, she invariably calls herself, not wife of Seleucus or Antiochus, but daughter of Demetrius, ${ }^{103}$ and this $I$ think gives the clue. The reason personal to herself for the foundation of the Stratoniceia was just this, that she was the daughter of Demetrius; and as the actual foundation seems to have been made by Antigonus on her behalf, ${ }^{104}$ the same considerations should apply to the Antigoneia. We know that a distinguishing characteristic of the earlier Antigonids was pietas, affection for their fathers, as appears in many well-known stories: Plutarch shows that Gonatas had this quality in full measure, ${ }^{105}$ while for Stratonice her offerings at Delos speak.

The foundations of 254 then were pious foundations; they were not the result of victories or alliances, but were founded by the brother and sister in the character of children of Demetrius, sometime lord of the Aegean. Such pious foundations could hardly have been refused by the priests during

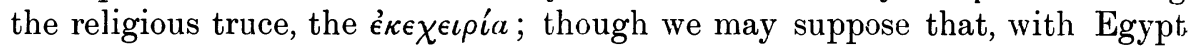
at the time occupied elsewhere, Antigonus had force enough on the spot to overcome any scruples.

102 This fête cannot have been founded by, or for, the younger Stratonice, on her marriage, as there must then have been a Demetrieia also ; besides, the proceeding would have been pointless.

103 A comparison of Stratonice's offerings in the inventory of Hypsocles $(279 \mathrm{H} .=281$, B.C.H. xiv. pp. 389 seq.) with those in the inventories of Sosisthenes $(250 \mathrm{H} .=252, B . C . H$. xxvii. pp. 62 seq.) and Demares (180, B.C.H. vi. p. $1=$ Dittenb. Syll. $\left.{ }^{2} 588\right)$, shows that many of her offerings are later than 281, i.e. long after her marriage. The description $\beta \alpha \sigma i \lambda \iota \sigma \sigma \alpha$

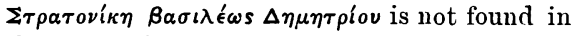
the earlier inventory but only in the two later ones, in connection with offerings not found in the earlier inventory. She uses the same description in the inscription of unknown provenance in honour of Arsinoe, Dittenb. O.G.I. 14, which, judging by the Delian inventories, can hardly be as early as Dittenberger puts it. The connection between Demetrius and Delos is further illustrated by the silver models of a trireme and quadrireme dedicated by Seleucus at Delos, doubtless in celebration of his marriage

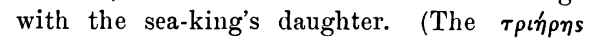

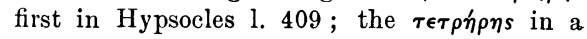
fragment of an inventory published by Diirrbach, B.C.H. xxix. p. 543 , No. 182, and p. 563. Homolle called the $\tau \rho\llcorner\eta$ p $\eta$ s a vase; but though Dïrbach also calls the $\tau \epsilon \tau \rho \dot{\eta} \rho \eta s$ a vase, no vase of that name is known, and I cannot. agree with him that there is no doubt that a $\tau \in \tau \rho^{\prime} \rho \eta \bar{s}$ of $1700 \mathrm{drachm}$. is the same as a

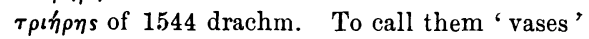
misses the whole point of these offerings.)

${ }^{104}$ Schulhof, l.c. ; in the inventories of Sosisthenes and Acridion the formula is $\chi o \rho \epsilon l a \dot{v} \pi \dot{\epsilon} \rho$ $\beta a \sigma \iota \lambda \ell \sigma \sigma \eta s \mathbf{\Sigma} \tau \rho \alpha \tau o \nu i \kappa \eta s$.

105 Plut. Dem. 51. 
For of course his pious foundation had a second meaning. It was a direct and deliberate challenge to Ptolemy, a plain statement that the son of Demetrius was now ready to fight for his father's inheritance. Antigonus may have even lorded it over Delos a little while de facto; but I do not see how his portico can belong to this epoch; ${ }^{106}$ he must have known that he could never hold Delos till he had reckoned with the great sea-power to whom he had thrown down the gauntlet.

The old voluptuary of Alexandria raised the gauntlet after his own fashion. He did not man his fleet and sail for Corinth; but it happened that Antiochus II. repudiated his wife Laodice and married Ptolemy's daughter, swinging Syria over from Macedonia to Egypt, and it happened that Antigonus' governor Alexander revolted ${ }^{107}$ and carried with him Corinth and Chalcis, immobilising, even if not actually possessing himself of, the new fleet, and giving Antigonus another dreary war. All that remained for Ptolemy to do was to emphasise his bloodless victory by a fresh foundation at Delos, the second Ptolemaieia in 250 (Badros' year); it was a proclamation to the world that he was still lord of the Aegean. ${ }^{108}$

But political combinations provide no permanent substitute for effective force; neither could they postpone for ever the only material question, whether the Egyptian marines could face Antigonus' Macedonians. In 247 the whole diplomatic erection fell like a house of cards. Alexander died, ${ }^{100}$ and Antigonus, by a mixture of diplomacy and sheer audacity, regained Corinth, his indispensable base. Antiochus died, and the repudiated wife sought instant vengeance on her Egyptian rival. Philadelphus died, perhaps amid warlike preparations, leaving his son to extricate his sister from Antioch, if he could, and to face the persevering old Macedonian, to whom Laodice's party were bound to turn for help, and who must have known that it was now or never. Euergetes, we may suppose, started as early in the spring of 246 as possible; with that part of his fleet which was at Cyprus he made his dash for Antioch, and entered the city, though too late to save his sister; Seleucus was driven over the Taurus; Sophron, who had handed over Ephesus to Ptolemy, received the command of the Egyptian squadron at Samos, with orders to watch Antigonus. Antigonus sailed; Sophron was

106 Where Holleaux places it, C.R. Acad. Inscr. 1907, p. 338. M. Holleaux is a strong follower of Beloch for this period.

107 I follow Beloch here, as against de Sanctis in Klio ix. 1.

108 There is no evidence whatever that Antigonus at this time conquered some Cyclades, which Philadelphus afterwards reconquered. The supposed Macedonian possession of Audros about 250 (Homolle, Arch. 65 ; Beloch, Gr. Gesch. iii. 2, 433) is based on nothing but the arbitrary alteration of a proper name in Plut. Arat. xii., a chapter whose problems still await solution. But of course
Antigonus may lave fought a sea-fight of some kind in 254. Many such must have dropped out of our mutilated tradition : e.g. Leucas, B.C.H. xxviii. 164, No. 56, 1. 22, which cannot be placed.

109 Sokolow's date, Klio iii. 119. Quite apart from the fact that Antigonus must have regained Corinth before he could undertake the naval campaign of 246 , I agree with de Sanctis, Klio, ix. p. 7, that the words attributed to Antigonus in Plut. Arat. 15 must have been spoken, or supposed to have been spoken, before Euergetes' successful land campaign; and Antigonus in Arat. 15 already has Corinth. 
defeated at Andros, perhaps without great loss, ${ }^{110}$ and fell back on his base at: Samos. It is probable too that at the same time another Egyptian squadron under Chremonides was defeated by the Rhodians under Agathostratus; ${ }^{111}$ for the policy of Rhodes was always to intervene against the aggressor so as to preserve, if possible, the balance of power, ${ }^{112}$ and she could not afford to see Seleucus crushed. The season must have closed with Antigonus' voyage across the Aegean in search of his beaten enemy, and the decisive defeat of the combined and in all probability numerically ${ }^{113}$ superior forces of Egypt at Cos.

We can gather from subsequent events that the war, so far as concerns Antigonus, must have closed with a definite peace with Egypt; and from the shape that the terms of peace appear to have taken, it looks as if Euergetes: agreed with his Macedonian adversary quickly, while still facing Seleucus. Antigonus was old, and knew what was possible; Egypt was still powerful; it was no part of his policy to try to crush her merely for Seleucus' benefit. We should expect a peace which, while securing to him the indispensable fruit of his victories, did something to save Ptolemy's face. Ptolemy meanwhile, after his first successes on land, was suffering both from Seleucus' triumphant return over the Taurus and from sedition at home: he had to buy off one of his opponents, at a price. What we can deduce about the peace follows these lines. Antigonus got Delos and the Cyclades, and no more. Egypt continued to hold the southern limit of the Aegean, following the volcanic deep-water line, with a ring of posts at Methana, ${ }^{114}$ Thera, ${ }^{115}$ Astypalaea, ${ }^{116}$ Samos, ${ }^{117}$ and she remained free to expand northward at pleasure along the coasts of Asia Minor and Thrace, ${ }^{118}$ i.e. in the Seleucid sphere. But the Cyclades were, and remained, lost to Egypt. ${ }^{119}$ Gonatas had

110 The Paneia would suppose a 'panic' victory.

111 Dittenb. Syll. ${ }^{2} 224$; Polyaen. 5, 18.

112 She fought in turn against Demetrius I., Antiochus III., Philip V., always with the simo object.

113 The stories in Plutarch (see § B) show that Egypt was numerically superior in at least one of the battles; and the course of events naturally suggests Cos rather than Andros.

${ }_{114}$ Arsinoe in the Peloponnese, 1.G. xii. 3, 466, if the jdentification with Methana in the Argolid be correct; the name points to Philadelphus' time. Methana was still Egyptian under Philometor, Dittenb. O.G.I. 115. See Beloch, Gr. Gesch. iii. 2, p. 283 ; Dittenb. $S_{y j l l .}^{2} 261$, n. 11 . It may of course have been lost to Egypt, and recovered again later.

115 Egyptian from Philadelphus onwards. Hiller von Gaertringen, Thera, passim, and esp. vol. i. pp. 162-165. It is more than doubtful if it ever belonged to the League.

116 C.I.G. ii. 2492 ; the Euergetes is doubtless Ptolemy III.
117 Headquarters of the Egyptian Aegean fleet under Philadelphus, Dittenb. Syll. ${ }^{2} 202$ (the oNicourgia decree), and under Philopator, Polyb. v. 35; doubtless also under Euergetes. If lost in the revolt of the younger Ptolemy, it must have been recovered on his death.

113 The Adulis Inscription shows that the conquests in the Hellespont and Thrace were made by Euergetes, but at what period of his reign is uncertain. Polyb. v. 34. 7-8, though put generally, refers merely to the reign before Philopator; it has no bearing on the history of the Cyclades, to which it does not allude.

119 There is no further trace of Egyptian Cyclades. The two cases quoted by Beloch, Gr. Gesch. iii. 2, p. 282, Siphnos and "perhaps" Keos, are now placed earlier. The Siphnos decree in houour of Perigenes, I.G. xii. 5, 481, Arch. für Pap. ii. 545, n. 23, Dittenb. O.G.I. 730 , has been shown by Holleaux, B.C.H. xxix. (1905) p. 319, not to refer to Philopator's admiral, but to belong to the reign of Philadelphus; and a further part of the decree of Carthaia_in Keos in honour of Philotheros, 
Delos, ${ }^{120}$ and the prestige which only Delos could confer; there he could build his portico to Apollo in peace, and set up the statues of his ancestors. Demetrius II. inherits peacefully; he founds the Demetrieia at Delos in 239 to celebrate his accession; he acts as referee, just as Philadelphus had done in his time, to one of the island cities of the League; ${ }^{121}$ and though the events of his reign on land must have excluded the possibility of much naval activity, he goes further afield than his father and obtains a footing in Crete, the halfway house between the archipelago and Egypt. ${ }^{122}$ Lastly, Doson, though he makes no accession foundation at Delos, acts as lord of the island and marks its importance by there setting up the record of his great victory over Cleomenes; he continues the Cretan policy of Demetrius, ${ }^{123}$ and strikes at Egypt, as Gonatas had done, at the S.W. corner of Asia Minor, the knot of her naval communications. Whether the inscriptions which show us an Antigonus exercising authority in Syros, Amorgos, and even in Cos, ${ }^{124}$ refer to Gonatas or Doson cannot at present be decided.

W. W. TARn.

I.G. xii. 5, 1, 533 (C.I.G. ii. 2356), has been discovered by M. Paul Graindor (Musée Belge xi. 1907, p. 98), who shows from the lettering of the new fragment that the decree goes back at least to the period of Philocles. 1 may note that I am entirely omitting here the interesting question, whether, and if so, how far and in what shape the League still existed after the Macedonian conquest.

${ }^{120}$ Further as to this in my subsequent paper.

121 Poeëssa in Keos. See Graindor in Musée Bclge xi. p. 104, no. 5 on I.G. xii. 5, 570. Seealso as ro Demetrius II.'s position at Delos the decree of Delos in honour of Hierocles (or Autocles), B.C.H. xiii. (1889), p. 232, n. 2 ; Holleaux in
Revue des Études Anc. v. (1903), p. 209, no. 5 ; P. Roussel in B.C.H. xxxi. (1907), pp. 362-3. The non-recognition of the position of Demetrius. II. in the Aegean is to some extent responsible for the Doson heresy.

${ }^{122}$ Inscr. of Gorty $\rightarrow$ F. Halbherr in Amer. Journ. Arch. 1897, p. 188 , no. 17.

${ }^{123}$ Treaties with Eleuthernae and Hierapytna, B.C.H. xiii. p. 47 , nos. 1,2 ; Rev. Philol. xxvi. (1902), p. 301, nos. 7, 8. See n. 39.

124 J. Delamarre, Rev. Philol. xxvi. 301, nos. 1-6 inclusive. The decree of Cos, no. 6 (=Newton, Gr. Inscr. B..1Y. $247=$ CollitzBechtel, 3611), seems, almost certainly Doson. Good discussion of Doson's position by Holleaux, B.C.H. xxxi. pp. $94 s c q$. 